\title{
Cyclic Voltammetric Studies of the Behavior of Lead-Silver Anodes in Zinc Electrolytes
}

\author{
W. Zhang, C.Q. Tu, Y.F. Chen, W.Y. Li, and G. Houlachi
}

\author{
(Submitted November 18, 2011; in revised form November 25, 2012; published online December 21, 2012)
}

\begin{abstract}
Cyclic voltammetry (CV) for lead-silver anodes has been performed in an acidic zinc sulfate solution with and without $\mathrm{Mn}^{2+}$ at $38{ }^{\circ} \mathrm{C}$. It has been found that the most redox peaks observed at the lowest sweep rate of $3 \mathrm{mV} / \mathrm{s}$ in the sulfate solution could be characterized by the Nernst equation. Bubbling argon into the zinc electrolyte and increasing the potential sweep rates from 3 to $300 \mathrm{mV} / \mathrm{s}$ did not change the shape of the CV diagrams. It was also found that $0.7 \%$ silver as alloying element had an important influence on the reactions of $\mathrm{Pb}-\mathrm{Ag}$ anodes in the zinc electrolyte. Lead-silver alloys were oxidized more easily in sulfuric acid than in the examined zinc electrolyte. The addition of $\mathrm{MnSO}_{4}$ to the zinc electrolyte decreased the numbers of the redox peaks on the curve of $\mathrm{CV}$ for lead-silver anode in zinc electrolyte.
\end{abstract}

Keywords cyclic voltammetry, lead-silver alloy anodes, zinc electrolyte

\section{Introduction}

Insoluble anodes are widely used in industrial hydrometallurgical processes. A useful anode material must meet three requirements: electrical conductivity, electrocatalysis, and stability. Most hydrometallurgical processes use sulfuric acid solutions. The main anodic reaction is oxygen evolution by decomposition of water. In these solutions, the predominant anode materials have been different lead alloys used as anodes. However, pure lead has many disadvantages: higher overpotential, and more corrosion products; also, pure lead is a weak material and it tends to creep and warp during use. Therefore, lead must be alloyed to improve at least its mechanical properties (Ref 1).

Small amounts of $\mathrm{Ag}(0.7-1.0 \%)$ alloyed with lead decrease the oxygen overvoltage, and increase the corrosion resistance of material. A well-established custom in many electrolytic zinc plants is to use $\mathrm{Pb}-\mathrm{Ag}$ alloys containing $0.7-1.0 \% \mathrm{Ag}$ as the anode material (Ref 2$)$.

Addition of $\mathrm{MnSO}_{4}$ to the zinc electrolyte results in the formation of $\mathrm{MnO}_{2}$ protective film on the surface of $\mathrm{Pb}$ electrode during electrolysis. This helps in minimizing the $\mathrm{Pb}$ content of the zinc deposits (Ref 3 ).

$25 \mathrm{w}$ ? $>$ Cyclic voltammetry $(\mathrm{CV})$ has been widely used to investigate the electrochemical behavior of metal materials.

W. Zhang, School of Metallurgical Engineering, Hunan University of Technology, Zhuzhou 412007, Hunan, China; and Department of Mining, Metallurgy and Material Engineering, Laval University, Ste-Foy, QC G1K 7P4, Canada; C.Q. Tu and W.Y. Li, China National South Aviation Industry Co. Ltd., Zhuzhou 412002, Hunan, China; Y.F. Chen, School of Metallurgical Engineering, Hunan University of Technology, Zhuzhou 412007, Hunan, China; and G. Houlachi, LTE, Hydro-Quebec, 600 Avenue de la Mortagne, C.P. 900, Shawinigan, QC G9N 7N5, Canada. Contact e-mail: weizhang716@hotmail.com.
However, the electrochemical behavior of lead-silver electrodes in aqueous sulfuric acid solution has rarely been investigated using CV. The electrochemical behavior of lead electrodes in aqueous sulfuric acid has, however, been researched by many people using CV. For example, Yamamoto et al. (Ref 4) have investigated the electrochemical behavior of pure lead electrode in aqueous sulfuric acid solution, and they have studied almost all the peaks of the lead electrodes in the whole potential region of the positive and negative electrodes for a lead-acid cell in aqueous sulfuric acid solutions. They found that several redox peaks appeared concerning the active materials of lead electrode: the oxidation peaks are $\mathrm{Pb} \rightarrow \mathrm{PbSO}_{4}, \mathrm{PbO} \rightarrow \alpha-\mathrm{PbO}_{2}$, $\mathrm{PbSO}_{4} \rightarrow \beta-\mathrm{PbO}_{2}$, and $\mathrm{H}_{2} \mathrm{O} \rightarrow \mathrm{O}_{2}$; and the reduction peaks are $\mathrm{PbO}_{2} \rightarrow \mathrm{PbSO}_{4}, \mathrm{PbO} \rightarrow \mathrm{Pb}$, and $\mathrm{PbSO}_{4} \rightarrow \mathrm{Pb}$ (Ref4-6).

Pavlov et al. (Ref 7) suggested that the oxidation of $\mathrm{PbSO}_{4}$ to $\mathrm{PbO}_{2}$ occurs when the electrode potential is sufficiently high to allow the oxidation of $\mathrm{PbSO}_{4}$. The $\mathrm{PbSO}_{4}$ crystals are dissolved as $\mathrm{Pb}^{2+}$ and $\mathrm{SO}_{4}{ }^{2-}$ into the solution in the pores of the lead anodic film. The $\mathrm{Pb}^{2+}$ ions diffuse to the nearest reaction site where they are oxidized to $\mathrm{Pb}^{4+}$ ions. As the $\mathrm{Pb}^{4+}$ ions are thermodynamically unstable in solution, they combine with water to form $\mathrm{Pb}(\mathrm{OH})_{4}$ which then is dehydrated to form $\mathrm{PbO}(\mathrm{OH})_{2}$, and finally converted to form $\mathrm{PbO}_{2}$ (Ref 7, 8).

Ijomah (Ref 9) observed that the anodic curves (essentially flat within the passive region) failed to confirm the presence of some compounds apparently reduced in the cathodic sweep. Consequently, the anodic curve was fully expanded ten times over the passive range to identify any current peaks previously missed on the higher scale and to permit meaningful comparison between different alloys. In the expanded plot, Ijomah (Ref 9) found that the current actually wavered in the passive region, and that some peaks or humps were observed corresponding to formation of lead monoxide $(\mathrm{PbO})$, and lead dioxide $\left(\alpha-\mathrm{PbO}_{2}\right)$ beneath the lead sulfate film.

Czerwinski et al. (Ref 10) also observed that the redox reactions occurring on the $\mathrm{Pb}$ electrode in sulfuric acid solutions are complex and depend on many variables, like the concentration of acid, the sweep rate in CV experiments, and temperature. When the lead dioxide formed at high position potentials is reduced $\left(\mathrm{PbO}_{2} \rightarrow \mathrm{PbSO}_{4}\right)$, a large increase of 
molar volume is expected, and as a result, the surface cracks, exposing the bare metal. The surfaces of bare metal are then oxidized. They also found that the change of a sweep rate does not influence to a great extent the shape of CVs at low concentrations of sulfuric acid.

Understanding the electrochemical behavior of pure lead anode in sulfuric acid should help us to improve the performance of $\mathrm{Pb}-\mathrm{Ag}$ anodes in electrowinning electrolytes.

The CV has been used to investigate the mechanism of the reactions taking place on $\mathrm{Pb}-\mathrm{Ag}$ alloy anodes in a sulfuric acid and acidic zinc sulfate electrolytes; it has been shown that with increasing anodic polarization, first an insulating film of $\mathrm{PbSO}_{4}$ and then conductive layers of $\mathrm{PbO}_{2}$ are successively formed on the electrode (Ref 11).

In this article, we attempt to interpret the peaks appearing on the CV diagrams of lead-silver alloy electrodes in the whole scanned potential region in zinc electrolyte. The main purpose of this study is to characteristic each current peak to a corresponding reaction and to examine the influence of various conditions on the position and the heights of these peaks.

\section{Experimental}

\subsection{Materials and Sample Preparation}

The four types of solution were used in this study: (1) $180 \mathrm{~g} / \mathrm{dm}^{2}$ of $\mathrm{H}_{2} \mathrm{SO}_{4}$; (2) $60 \mathrm{~g} / \mathrm{dm}^{3}$ of $\mathrm{Zn}^{2+}\left(\mathrm{ZnSO}_{4} \cdot 7 \mathrm{H}_{2} \mathrm{O}\right)$ and $180 \mathrm{~g} / \mathrm{dm}^{3}$ of $\mathrm{H}_{2} \mathrm{SO}_{4}$; (3) $60 \mathrm{~g} / \mathrm{dm}^{3}$ of $\mathrm{Zn}^{2+}, 180 \mathrm{~g} / \mathrm{dm}^{3}$ of $\mathrm{H}_{2} \mathrm{SO}_{4}, 250 \mathrm{mg} / \mathrm{dm}^{3}$ of $\mathrm{Cl}^{-}$, and $3 \mathrm{mg} / \mathrm{dm}^{3}$ of glue (gelatin or glue $(\mathrm{G})$ is an animal protein that consists of a complicated mixture of polypeptides and is used as leveling agent (Ref 12)); and (4) $60 \mathrm{~g} / \mathrm{dm}^{3}$ of $\mathrm{Zn}^{2+}, 180 \mathrm{~g} / \mathrm{dm}^{3}$ of $\mathrm{H}_{2} \mathrm{SO}_{4}, 8 \mathrm{~g} / \mathrm{dm}^{3}$ of $\mathrm{Mn}^{2+}, 250 \mathrm{mg} / \mathrm{dm}^{3}$ of $\mathrm{Cl}^{-}$, and $3 \mathrm{mg} / \mathrm{dm}^{3}$ of glue heated by a flow of thermostatted water in the double wall $\left(38 \pm 0.5^{\circ} \mathrm{C}\right)$.

Zinc sulfate $\left(\mathrm{ZnSO}_{4} \cdot 7 \mathrm{H}_{2} \mathrm{O}\right)$ and manganese sulfate $\left(\mathrm{MnSO}_{4} \cdot \mathrm{H}_{2} \mathrm{O}\right)$ from Sigma-Aldrich Fine Chemicals, and sodium chloride and sulfuric acid from Merck KGaA were used to prepare the supporting electrolyte with double distilled water. Gelatin (glue) was product of BDH Inc. The chemicals meet ACS specifications (except gelatin) and were used as received without further treatment. All concentrations of $\mathrm{H}_{2} \mathrm{SO}_{4}$ and $\mathrm{Zn}^{2+}$ stated in this article are initial concentrations.

The lead-silver anode tested in this study was a laminated $\mathrm{Pb}-0.7 \%$ Ag lead-silver alloy (RSR, Texas, USA). The original surface was removed, and only the bulk was used. The cathodes were made of platinum. The $\mathrm{Pb}-\mathrm{Ag}$ alloy plates were cut into small pieces of $1 \times 1 \times 1 \mathrm{~cm}^{3}$, which then were connected with a plastic isolated copper wire and cast in acrylic resin. The exposed area surface was $1 \mathrm{~cm}^{2} ; 99.99 \%$ pure lead electrodes were made of a round rod with a diameter of $9 \mathrm{~mm}$; and the working surface was $0.636 \mathrm{~cm}^{2}$. Before being introduced into the electrolytic cell, these working surfaces of the anodes and cathodes were ground with $\mathrm{SiC}$ abrasive paper (Leco Corporation) down to 600 grit, washed with double distillated water, and wiped immediately with tissue paper.

\subsection{Experimental Setup}

The electrolytic cell comprised a one-liter double-walled beaker containing $800 \mathrm{~mL}$ of electrolyte heated by a flow of thermostated water in the double wall $\left(38 \pm 0.5{ }^{\circ} \mathrm{C}\right)$. The working electrode and the counter electrode were mounted in suitable Teflon-made holder, and the distance between them was fixed at $2 \mathrm{~cm}$. The reference electrode was mercurous sulfate electrode (MSE): $\mathrm{Hg}, \mathrm{Hg}_{2} \mathrm{SO}_{4} /$ sat $\cdot \mathrm{K}_{2} \mathrm{SO}_{4}(0.636 \mathrm{~V}$ versus SHE). A saturated $\mathrm{K}_{2} \mathrm{SO}_{4}$ salt bridge was used to keep the reference electrode close to the cathode. The experimental setup was an EG\&G PARSTAT 2263 potentiostat/galvanostat controlled by an IBM computer.

The standard ASTM-61 (Ref 13) was used to carry out cyclic potentiodynamic polarization. The cyclic potentiodynamic were traced at $100 \mathrm{mV} / \mathrm{s}$ scanning rate. For $\mathrm{Pb}-\mathrm{Ag}$ alloy electrodes, the range was from -300 to $1800 \mathrm{mV}$ versus OCP. All potentials are given with respect to SHE reference electrode. The reproducibility of the potential values was of the order of $\pm 10-15 \mathrm{mV}$, and the reproducibility of the corrosion current values was also of the order of $\pm 10-15 \%$. All the experiments were repeated three times.

\section{Results and Discussion}

\subsection{Lead-Silver Alloy and Pure Lead in a Sulfuric Acid}

Figure 1 shows a cyclic voltammogram of the lead-silver electrode in $180 \mathrm{~g} / \mathrm{dm}^{3}$ sulfuric acid solution. The potential region investigated ranged from -0.7 to $2.4 \mathrm{~V}$. There are eight redox peaks on the curve. The electrochemical reactions corresponding to each peak are given as follows based on the literature. During the anodic sweep, three oxidation peaks were observed. The oxidation peak I should correspond to Reaction (1):

$\mathrm{Pb}+\mathrm{SO}_{4}^{2-} \rightarrow \mathrm{PbSO}_{4}+2 e$.

This reaction leads to the formation of a nonconducting lead sulfate layer, i.e., the passivation of the anode.

The concentration of $\mathrm{SO}_{4}{ }^{2-}$ was considered instead of the activity of $\mathrm{SO}_{4}{ }^{2-}$, since there are no precise data available about the $\mathrm{SO}_{4}{ }^{2-}$ activity. The corresponding Nernst equation is (Ref 14):

$$
\begin{aligned}
E & =E^{\circ}-(R T / 2 F) \ln \mathrm{SO}_{4}^{2-}=-0.356-0.0308 \log \mathrm{SO}_{4}^{2-} \\
& =-0.356-0.0308 \log 2.25=-0.367 \mathrm{~V} .
\end{aligned}
$$

This agrees well with the potential on almost halfway between peak I and its corresponding reduction peak VIII. These peaks can therefore be reliably assigned to anodic formation of lead sulfate by Eq 1 and its corresponding reduction back to lead.

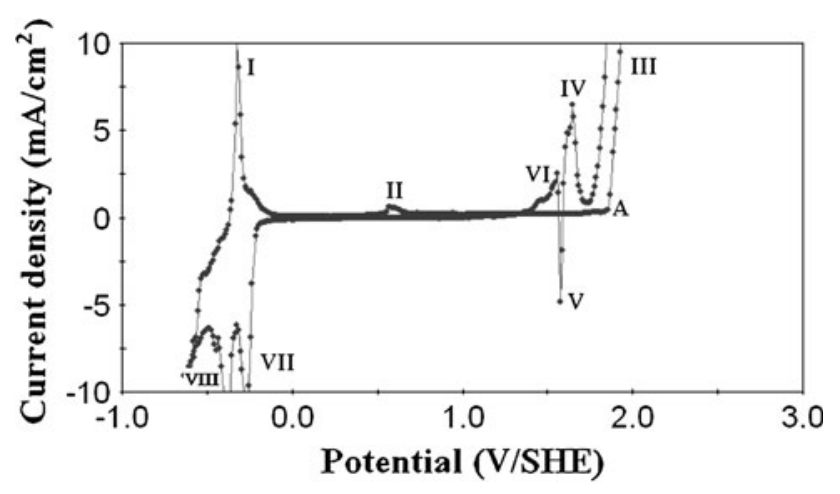

Fig. 1 Cyclic current-potential curve of the lead-silver alloy anode in a sulfuric acid solution $180 \mathrm{~g} / \mathrm{dm}^{3} \mathrm{H}_{2} \mathrm{SO}_{4}$ at a scan rate of $3 \mathrm{mV} / \mathrm{s}$ 
After the appearance of these peaks, the current drops to a very low value indicative of the attainment of passivity and remained essentially constant at this residual value for a considerable range of potentials (i.e., the passivation region) before rising again owing to the formation of the silver sulfate. Jones and Thirsk (Ref 15) stated that $\mathrm{Ag}_{2} \mathrm{SO}_{4}$ is formed at this plateau of the curve of $\mathrm{CV}$ in sulfuric acid solution and that the $\mathrm{Ag}_{2} \mathrm{SO}_{4}$ crystals grew mainly parallel to the silver additive surface. Hence, the peak II can correspond to the following reaction:

$2 \mathrm{Ag}+\mathrm{SO}_{4}^{2-}=\mathrm{Ag}_{2} \mathrm{SO}_{4}+2 e$.

The corresponding Nernst equation (Ref 15) is as follows:

$$
E=E^{\circ}+R T / 2 F \ln \left(\mathrm{Ag}^{+}\right)+(R T / 2 F) \ln \alpha_{\mathrm{SO}_{4}}^{2-}=0.62 \mathrm{~V} .
$$

Deutscher et al. (Ref 16) found that region A corresponds to the nucleation and growth of $\beta-\mathrm{PbO}_{2}$ from $\mathrm{PbSO}_{4}$.

$\mathrm{PbSO}_{4}+2 \mathrm{H}_{2} \mathrm{O} \rightarrow \mathrm{PbO}_{2}+\mathrm{SO}_{4}^{2-}+2 e+4 \mathrm{H}^{+}$.

The corresponding Nernst equation is given by

$$
\begin{aligned}
E & =E^{\circ}+(R T / 2 F) \ln \left(\mathrm{H}^{+}\right)^{4}\left(\mathrm{SO}_{4}^{2-}\right)^{2}=1.712-0.1234 \mathrm{pH} \\
& +0.0308 \log \mathrm{SO}_{4}^{2-}=1.794 \mathrm{~V} .
\end{aligned}
$$

The molar volume of $\beta-\mathrm{PbO}_{2}\left(25 \mathrm{~cm}^{3} / \mathrm{mol}\right)$ is much less than the molar volume of $\mathrm{PbSO}_{4}\left(48 \mathrm{~cm}^{3} / \mathrm{mol}\right)$, and hence, gaps are created in the outer $\mathrm{PbSO}_{4}$ layer, and the bare metal is exposed to the acidic solution (Ref 16).

The peak III appeared from ca. $1.8 \mathrm{~V}$ and was the highest peak among all the peaks; it was due to the oxygen evolution on the $\beta-\mathrm{PbO}_{2}$ which is a good conductor.

$2 \mathrm{H}_{2} \mathrm{O} \rightarrow \mathrm{O}_{2}+4 \mathrm{H}^{+}+4 e$.

The corresponding Nernst equation is given by

$$
E=E^{\circ}+(R T / 4 F) \ln \left(\mathrm{H}^{+}\right)^{4}=1.23-0.0617 \mathrm{pH}=1.265 \mathrm{~V} .
$$

It is clear that the overpotential of oxygen is very high.

During the reverse sweep, five redox peaks were obtained. When the potential was scanned from peak III, the current dropped sharply; this is expected because lead dioxide was reduced to sulfate lead: $\mathrm{PbO}_{2} \rightarrow \mathrm{PbSO}_{4}$. Since the molar volume of $\mathrm{PbSO}_{4}$ is much higher than that of $\mathrm{PbO}_{2}$, this change in the molar dimensions of the surface layer generates cracks on the electrode surface, and the exposure of the metallic lead could then take place: $\mathrm{Pb} \rightarrow \mathrm{PbSO}_{4}$. Yamamoto et al. (Ref 4) characterized this peak IV with the following reactions:

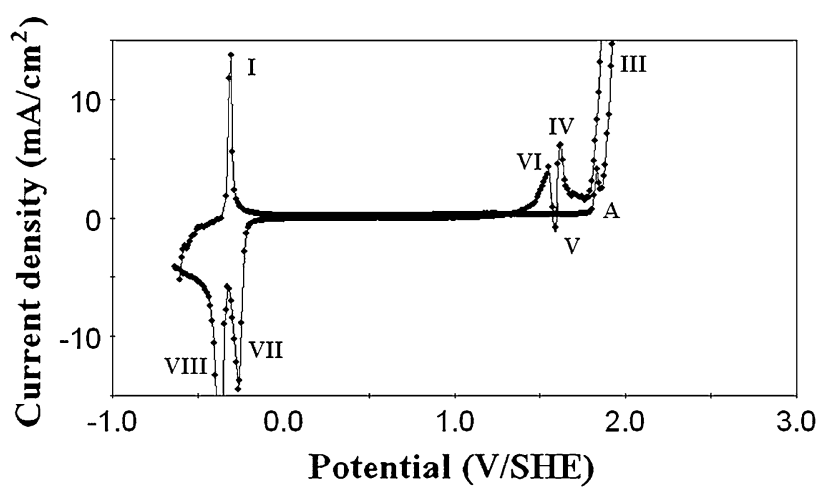

Fig. 2 Cyclic current-potential curve of the pure lead anode in a sulfuric acid solution $180 \mathrm{~g} / \mathrm{dm}^{3} \mathrm{H}_{2} \mathrm{SO}_{4}$ at a scan rate of $3 \mathrm{mV} / \mathrm{s}$
$\mathrm{PbO}_{2}+\mathrm{SO}_{4}^{2-}+2 e+4 \mathrm{H}^{+} \rightarrow \mathrm{PbSO}_{4}+2 \mathrm{H}_{2} \mathrm{O}$

and oxidation reaction (1).

The remaining $\mathrm{PbO}_{2}$ after peak IV continued to form $\mathrm{PbSO}_{4}$ (Eq 5), and this introduces peak V.

It is very plausible that the remaining or new bare lead is oxidized to $\mathrm{PbSO}_{4}$ to form peak VI. However, Danel and Plichon (Ref 17) stated that the Peak VI is relative to the oxidation of $\mathrm{Pb} \rightarrow \mathrm{PbO}$ at the potential ca. 1.5 versus SHE with overpotential being greater than $1.3 \mathrm{~V}$.

$\mathrm{PbO}+2 e+2 \mathrm{H}^{+} \rightarrow \mathrm{Pb}+\mathrm{H}_{2} \mathrm{O}$.

Finally, the peak VII corresponds to the reduction reaction $\mathrm{PbO} \rightarrow \mathrm{Pb}$ and the peak VIII corresponds to the reduction reaction: $\mathrm{PbSO}_{4} \rightarrow \mathrm{Pb}$ (Ref 4 ).

The passivity of lead in acid zinc sulfuric electrolyte was primarily due to the presence of a nonconducting lead sulfate film on the metal surface, apparently at a critical surface supersaturation of dissolving $\mathrm{Pb}^{2+}$ ions. Two theories, namely, 'solid state' and 'solution-precipitation' had so far been used to explain the phenomenon. In the solid-state mechanism, $\mathrm{PbSO}_{4}$ nucleation was believed to occur directly on the metal surface at a certain critical potential, followed by two- or threedimensional growth until the surface is fully covered. In the solution-precipitation mechanism, however, nucleation of $\mathrm{PbSO}_{4}$ was thought to occur in the solution, followed by its precipitation onto the metal surface. Here, the growth is always three-dimensional, and passivation is by a physical blocking action. The presence of intermediate compounds (i.e., $\mathrm{PbO}$. $\mathrm{PbSO}_{4}, \mathrm{PbO}$, and $\alpha-\mathrm{PbO}_{2}$ ) beneath the lead sulfate film, which had been confirmed by Ijomah (Ref 9). It was believed that a $\mathrm{pH}$ gradient existed in the lead sulfate film because of inhibited diffusion through the dense corrosion layer. No anodic peak was recorded for $\beta-\mathrm{PbO}_{2}$. The compound was believed to occur simultaneously with oxygen evolution (Ref 9).

The cyclic voltammogram of the pure lead electrode in $180 \mathrm{~g} / \mathrm{dm}^{3}$ sulfuric acid solution are presented in Fig. 2.

In this curve, the same peaks as Fig. 1 were found. These redox peaks correspond to the same redox reaction as those in Fig. 1 except absence of peak II. It means that adding $0.7 \% \mathrm{Ag}$ did not much change the shape of the cyclovoltammograms. However, the current of peak I $\left(\mathrm{Pb} \rightarrow \mathrm{PbSO}_{4}\right)$ of Fig. 2 is $40 \%$ higher than that of peak $\mathrm{I}\left(\mathrm{Pb} \rightarrow \mathrm{PbSO}_{4}\right)$ of Fig. 1. As reported by Mahato and Tiedemann (Ref 18), the value of peak

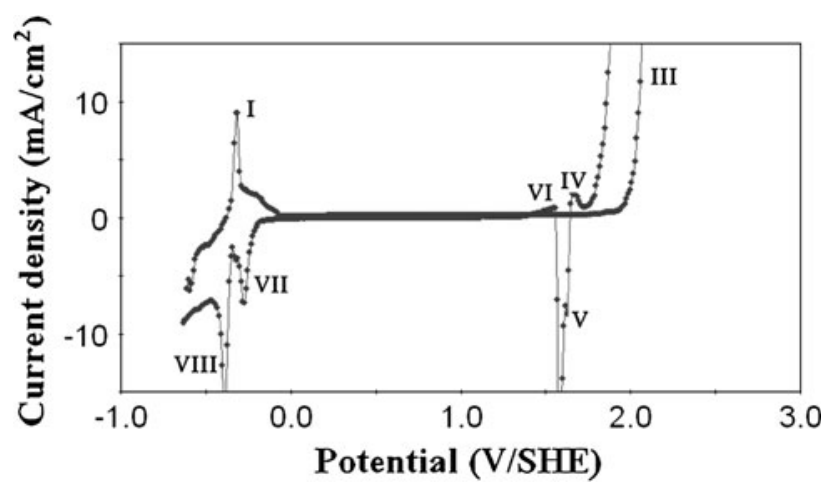

Fig. 3 Cyclic current-potential curve of the lead-silver alloy anode in zinc electrolyte containing $180 \mathrm{~g} / \mathrm{dm}^{3} \mathrm{H}_{2} \mathrm{SO}_{4}$, and $60 \mathrm{~g} / \mathrm{dm}^{3} \mathrm{Zn}^{2+}$, $250 \mathrm{mg} / \mathrm{dm}^{3}$ of $\mathrm{Cl}^{-}$, and $3 \mathrm{mg} / \mathrm{dm}^{3}$ of glue, at a scan rate of $3 \mathrm{mV} / \mathrm{s}$ 
I can be used to evaluate the corrosion rate of electrode. It means that a higher value of the peak corresponds to higher corrosion rate of the electrode. So the pure lead corrodes more readily than the lead-silver anode in the sulfuric acid solution.

\subsection{Lead-Silver Alloy in Zinc Electrolyte with and without $\mathrm{Mm}^{2+}$}

The cyclic voltammogram of the lead-silver alloy electrode in zinc electrolyte without $\mathrm{Mn}^{2+}$ is represented in Fig. 3.

In this curve, seven peaks appeared concerning the leadsilver anode in zinc electrolyte without $\mathrm{Mn}^{2+}$. The oxidation peak I corresponds to oxidation reaction (1).

Region A corresponds to the nucleation and growth of $\beta-\mathrm{PbO}_{2}$ from $\mathrm{PbSO}_{4}$ as oxidation reaction (3) (Ref 18).

The peak III was the highest peak among all the peaks; it corresponds to the oxygen evolution (4).

The irregular oxidation peak IV appeared at the outset in reversing the potential scan from a region of the oxygen evolution to the starting potential. This oxidation peak corresponds to bare metal oxidized to sulfate lead (1).

The peak $\mathrm{V}$ is related to the reduction of $\mathrm{PbO}_{2}$ into $\mathrm{PbSO}_{4}$; the peak VI should correspond to peak VI in Fig. 1, and this has been explained earlier corresponding to reactions (1) and (6).

Finally, the peak VII corresponded to the reduction reaction $\mathrm{PbO} \rightarrow \mathrm{Pb}$, and the peak VIII corresponded to the reduction reaction: $\mathrm{PbSO}_{4} \rightarrow \mathrm{Pb}$ (Ref 4).

A cyclic voltammogram for the lead-silver alloy anode in the zinc electrolyte with $\mathrm{Mn}^{2+}$ is shown in Fig. 4. There are six redox peaks on the curve.

As compared to Fig. 3, two oxidation peaks - $\mathrm{IV} \mathrm{Pb} \rightarrow$ $\mathrm{PbSO}_{4}$ (1) and $\mathrm{VI} \mathrm{Pb} \rightarrow \mathrm{PbO}$ (6)-have disappeared. As observed from the experiment, the red product of $\mathrm{MnO}_{4}{ }^{-}$and the evolution of oxygen appeared at the same time, and hence, the peak III corresponds to the reaction (4) and (7), and the standard potential of reaction (7) is $1.52 \mathrm{~V} / \mathrm{SHE}$ (Ref 19):

$\mathrm{MnSO}_{4}+4 \mathrm{H}_{2} \mathrm{O}-5 e=\mathrm{MnO}_{4}^{-}+\mathrm{H}_{2} \mathrm{SO}_{4}+6 \mathrm{H}^{+}$.

The present of permanganate ion can give rise to the formation of $\mathrm{MnO}_{2}$ :

$3 \mathrm{MnSO}_{4}+2 \mathrm{HMnO}_{4}+2 \mathrm{H}_{2} \mathrm{O}=2 \mathrm{MnO}_{2}+3 \mathrm{H}_{2} \mathrm{SO}_{4}$.

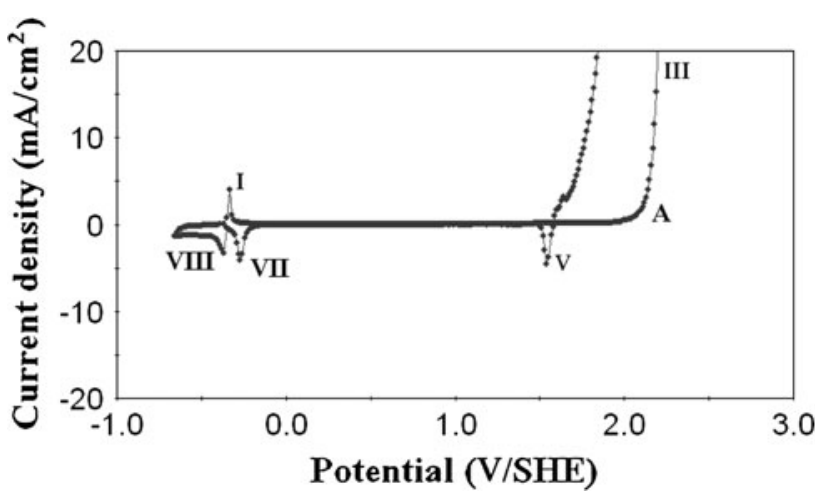

Fig. 4 Cyclovoltammogram of the lead-silver alloy anode in zinc electrolyte containing $180 \mathrm{~g} / \mathrm{dm}^{3} \mathrm{H}_{2} \mathrm{SO}_{4}, 60 \mathrm{~g} / \mathrm{dm}^{3} \mathrm{Zn}^{2+}$ and $8 \mathrm{~g} / \mathrm{dm}^{3}$ $\mathrm{Mn}^{2+}, 250 \mathrm{mg} / \mathrm{dm}^{3}$ of $\mathrm{Cl}^{-}$, and $3 \mathrm{mg} / \mathrm{dm}^{3}$ of glue at a scan rate of $3 \mathrm{mV} / \mathrm{s}$
Hence, a dense non-conductive $\mathrm{MnO}_{2}$ film formed on the surface of anode, the well-adherent oxide film $\mathrm{MnO}_{2}$, increased the thickness and the density of oxide layer $\left(\mathrm{PbO}_{2}-\mathrm{MnO}_{2}\right)$, which makes the transition of $\mathrm{Pb}^{2+}$ ions to the solution difficult and protects the lead anode from corrosion. Then, the $\mathrm{Pb}$ contamination of $\mathrm{Zn}$ deposit can be reduced because of the addition of $\mathrm{Mn}^{2+}$ to the zinc electrolyte.

The other redox peaks could be explained as follows: oxidation peak $\mathrm{I}, \mathrm{Pb} \rightarrow \mathrm{PbSO}_{4}$; reduction peak III, $\mathrm{PbO}_{2} \rightarrow$ $\mathrm{PbSO}_{4}$; reduction peak $\mathrm{IV}, \mathrm{PbO} \rightarrow \mathrm{Pb}$; and reduction peak $\mathrm{V}$, $\mathrm{PbSO}_{4} \rightarrow \mathrm{Pb}$. It was found that the three peak values were lower than that of the same reaction shown in Fig. 3, it means that less $\mathrm{Pb}$ is oxidized to $\mathrm{PbSO}_{4}$ compared to that in Fig. 3; hence, addition of $\mathrm{Mn}^{2+}$ to the zinc electrolyte inhibits the corrosion of lead anode.

Figure 5 shows the shape change of the cyclic voltammogram of the lead-silver electrode with various sweep rates.

In Fig. 5, most of redox peaks are the same as those in Fig. 3, and it was found from Fig. 5(a) that the height of oxidation peak I with the sweep rate increases. While in Fig. 5(b) at the sweep rate of 60 and $100 \mathrm{mV} / \mathrm{s}$ the reductive peak V (2) could be obtained, it was not observed in Fig. 3 and 5 (b) at the sweep rate of $20 \mathrm{mV} / \mathrm{s}$; the peak $\mathrm{V}$ (2) is possibly related to the reduction $\mathrm{PbO}_{2}$ into $\mathrm{PbO}$.

Also, the lead alloy anode was in zinc electrolyte containing $180 \mathrm{~g} / \mathrm{dm}^{3} \mathrm{H}_{2} \mathrm{SO}_{4}, 60 \mathrm{~g} / \mathrm{dm}^{3} \mathrm{Zn}^{2+} 250 \mathrm{mg} / \mathrm{dm}^{3}$ of $\mathrm{Cl}^{-}$, and $3 \mathrm{mg} / \mathrm{dm}^{3}$ of glue at the sweep rate of $3 \mathrm{mV} / \mathrm{s}$ under bubbling argon only before $\mathrm{CV}$ experiments $\left(5.5 \mathrm{~cm}^{3} / \mathrm{s}\right.$ for $800 \mathrm{~mL}$ electrolyte). it is observed that bubbling argon into the zinc electrolyte did not change the shape and number of redox peaks
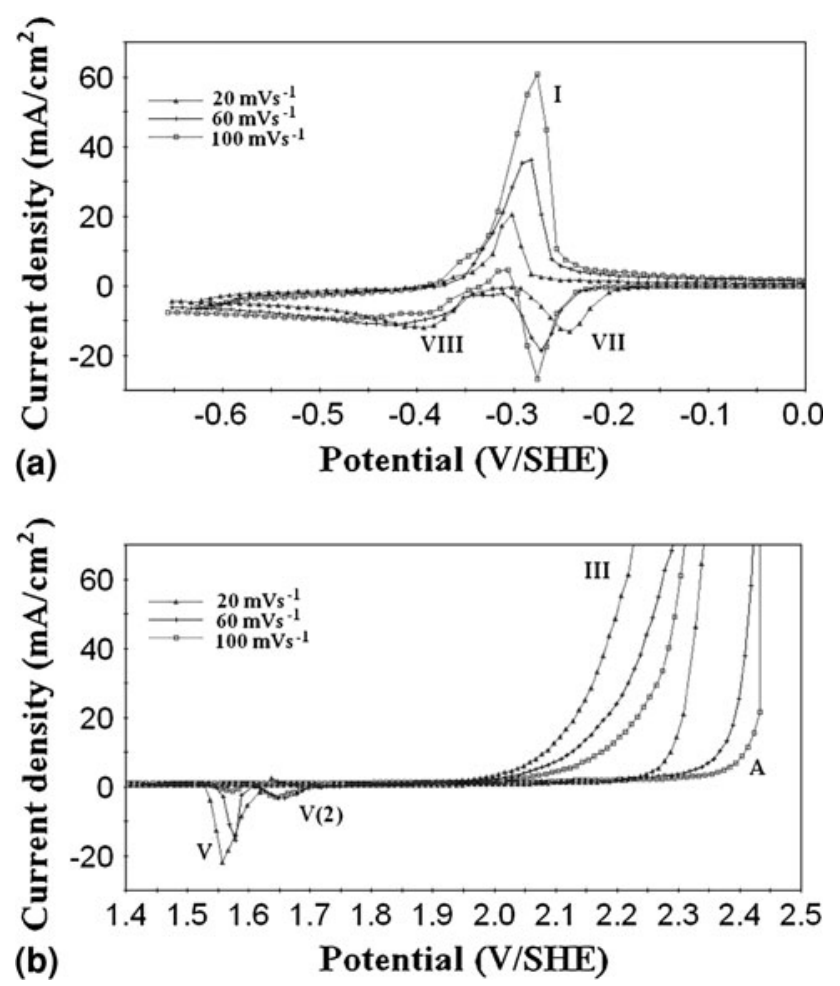

Fig. 5 Cyclic current-potential curve of the lead-silver alloy anode in zinc electrolyte containing $180 \mathrm{~g} / \mathrm{dm}^{3} \mathrm{H}_{2} \mathrm{SO}_{4}, 60 \mathrm{~g} / \mathrm{dm}^{3} \mathrm{Zn}^{2+}$, $250 \mathrm{mg} / \mathrm{dm}^{3}$ of $\mathrm{Cl}^{-}$, and $3 \mathrm{mg} / \mathrm{dm}^{3}$ of glue, at a scan rate of 20,60 , and $100 \mathrm{mV} / \mathrm{s}$ : (a) polarization range $-0.7-0 \mathrm{~V} / \mathrm{SHE}$; (b) polarization range 1.4-2.5 V/SHE 


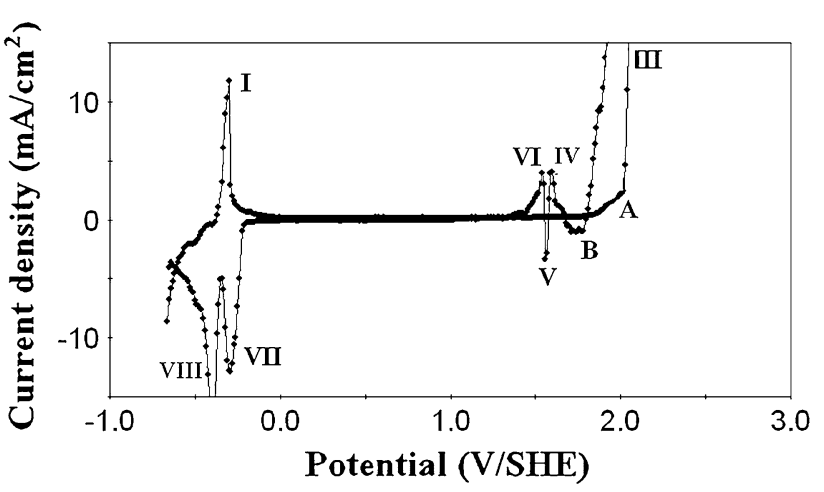

Fig. 6 Cyclic current-potential curve of the lead-silver alloy anode in zinc electrolyte containing $180 \mathrm{~g} / \mathrm{dm}^{3} \mathrm{H}_{2} \mathrm{SO}_{4}$, and $60 \mathrm{~g} / \mathrm{dm}^{3} \mathrm{Zn}^{2+}$, $250 \mathrm{mg} / \mathrm{dm}^{3}$ of $\mathrm{Cl}^{-}$, and $3 \mathrm{mg} / \mathrm{dm}^{3}$ of glue with aerated-oxygen at a scan rate of $3 \mathrm{mV} / \mathrm{s}$

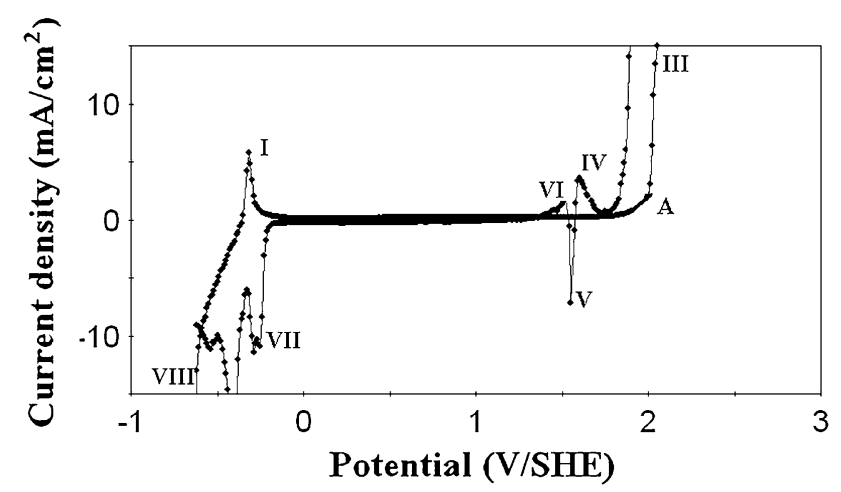

Fig. 7 Cyclic current-potential curve of the lead-silver alloy anode in zinc electrolyte containing $180 \mathrm{~g} / \mathrm{dm}^{3} \mathrm{H}_{2} \mathrm{SO}_{4}$, and $60 \mathrm{~g} / \mathrm{dm}^{3} \mathrm{Zn}^{2+}$, $250 \mathrm{mg} / \mathrm{dm}^{3}$ of $\mathrm{Cl}^{-}$, and $3 \mathrm{mg} / \mathrm{dm}^{3}$ of glue with aerated-oxygen and agitation, at a scan rate of $3 \mathrm{mV} / \mathrm{s}$

on the curve of $\mathrm{CV}$; this is because bubbling argon resulted in the absence of oxygen in the zinc electrolyte, and oxygen has a little influence on oxygen evolution, but does not have any influence on other redox equations. Also, adding argon to the zinc electrolyte resulted in stirring the solution, improving the diffusion of ions, and this could have influenced the effect on the redox equations.

However, when the lead alloy anode was in zinc electrolyte containing $180 \mathrm{~g} / \mathrm{dm}^{3} \mathrm{H}_{2} \mathrm{SO}_{4}, 60 \mathrm{~g} / \mathrm{dm}^{3} \mathrm{Zn}^{2+}, 250 \mathrm{mg} / \mathrm{dm}^{3}$ of $\mathrm{Cl}^{-}$, and $3 \mathrm{mg} / \mathrm{dm}^{3}$ of glue at the sweep rate of $3 \mathrm{mV} / \mathrm{s}$ with oxygen bubbling (volume of $5.5 \mathrm{~cm}^{3} / \mathrm{s}$ for $800 \mathrm{~mL}$ electrolyte) before experiment, some redox peaks could be obtained. Comparison of the redox peaks of Fig. 3, a reduction peak B only occurred on the curve (Fig. 6). This reduction peak B can correspond to: $\mathrm{O}_{2}+4 \mathrm{H}^{+}+4 e \rightarrow 2 \mathrm{H}_{2} \mathrm{O}$. Also, it was found that the oxide peaks of I, IV, and VI of Fig. 6 are higher than that of Fig. 3, while the reduction peak V of Fig. 6 is lower than that of Fig. 3, it means that the oxide agent $\mathrm{O}_{2}$ aerated into the zinc electrolyte is favorable to oxidation peak, but inhibits the occurrence of electrochemical reduction peak.

In practice, the electrolyte is always circulated with a certain speed, and it is important to simulate the influence of agitation of the electrolyte on the peaks of redox of lead-silver alloy anodes. Magnetic agitation was carried out by a stirrer (4-cm length and

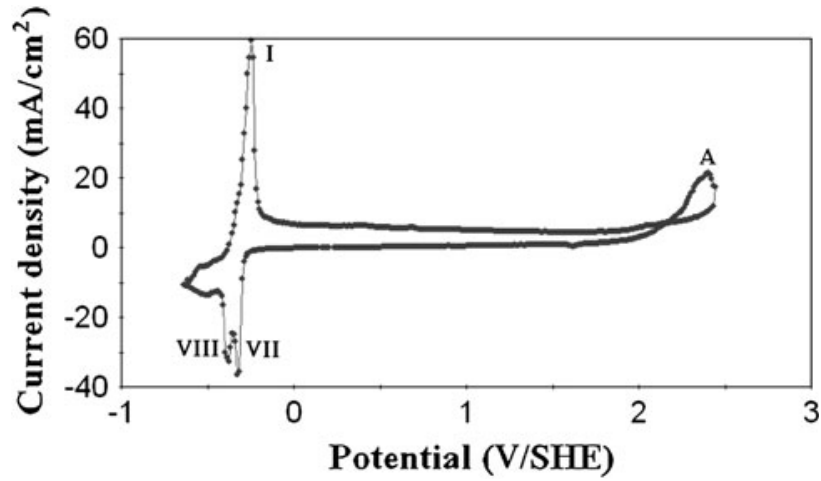

Fig. 8 Cyclic current-potential curve of the lead-silver alloy anode in the zinc electrolyte containing $180 \mathrm{~g} / \mathrm{dm}^{3} \mathrm{H}_{2} \mathrm{SO}_{4}, 60 \mathrm{~g} / \mathrm{dm}^{3} \mathrm{Zn}^{2+}$, $250 \mathrm{mg} / \mathrm{dm}^{3}$ of $\mathrm{Cl}^{-}$, and $3 \mathrm{mg} / \mathrm{dm}^{3}$ of glue at a scan rate of $300 \mathrm{mV} / \mathrm{s}$

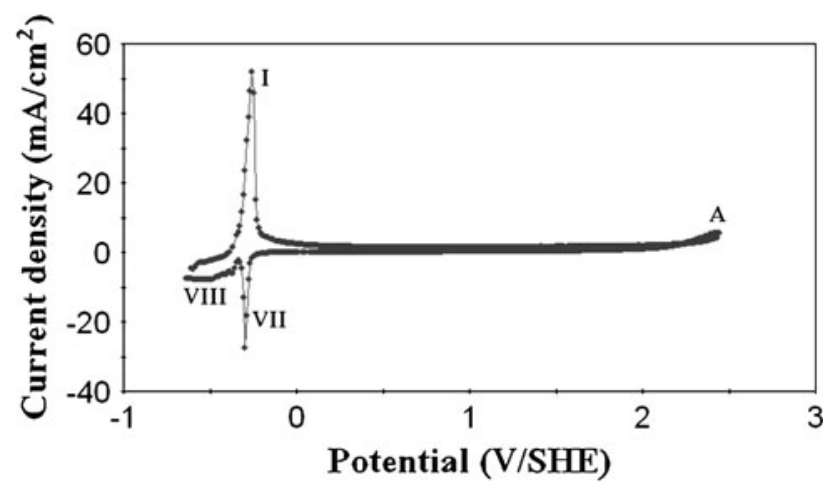

Fig. 9 Cyclic current-potential curve of the pure lead anode in the zinc electrolyte containing $180 \mathrm{~g} / \mathrm{dm}^{3} \quad \mathrm{H}_{2} \mathrm{SO}_{4}, \quad 60 \mathrm{~g} / \mathrm{dm}^{3} \quad \mathrm{Zn}^{2+}$, $250 \mathrm{mg} / \mathrm{dm}^{3}$ of $\mathrm{Cl}^{-}$, and $3 \mathrm{mg} / \mathrm{dm}^{3}$ of glue at a scan rate of $300 \mathrm{mV} / \mathrm{s}$

1-cm diameter) at $412 \mathrm{rpm}$, and the obtained curve is shown in Fig. 7.

When compared to Fig. 6 without agitation, the peak B (diffusion controlled peak of dissolved oxygen) disappeared, since agitation accelerated the diffusion of the solution with dissolved oxygen into the interface. Also, it was found also that the current value of oxidation peak I of Fig. 7 corresponding to the quantity of lead ions at the interface was lower than that without agitation of Fig. 6. The value of reduction peak $\mathrm{V}$ of Fig. 7 was higher than that of Fig. 6, since agitation favored the formation of lead sulfate by diffusion of the sulfuric acid electrolyte to the interface.

Figures 8 and 9 show the effects of the high sweep rate of $300 \mathrm{mV} / \mathrm{s}$ effects on the redox peaks of lead alloy anode in the zinc electrolyte containing $180 \mathrm{~g} / \mathrm{dm}^{3} \mathrm{H}_{2} \mathrm{SO}_{4}$, and $60 \mathrm{~g} / \mathrm{dm}^{3} \mathrm{Zn}^{2+}$.

In Fig. 8 and 9, oxygen evolution peak could not be obtained, but the oxidation peak of $\mathrm{PbSO}_{4} \rightarrow \mathrm{PbO}_{2}$ (A) has been found. Also Yamamoto et al. (Ref 4) observed that a peak current ascribed to $\beta-\mathrm{PbO}_{2}$ formation was clearly detected by $\mathrm{CV}$. It is then suggested (Fig. 5) that - at sweep rate from 20 to $100 \mathrm{mV} / \mathrm{s}$, the oxygen evolution peak also overlaps the reaction peak of $\mathrm{PbSO}_{4} \rightarrow \mathrm{PbO}_{2}$. Comparing Fig. 8 with Fig. 9, the current of peak $\mathrm{I}\left(\mathrm{Pb} \rightarrow \mathrm{PbSO}_{4}\right)$ of Fig. 8 is less $10 \mathrm{~mA} / \mathrm{cm}^{2}$ than that of Fig. 9. Also the current of peak $\mathrm{A}$ 


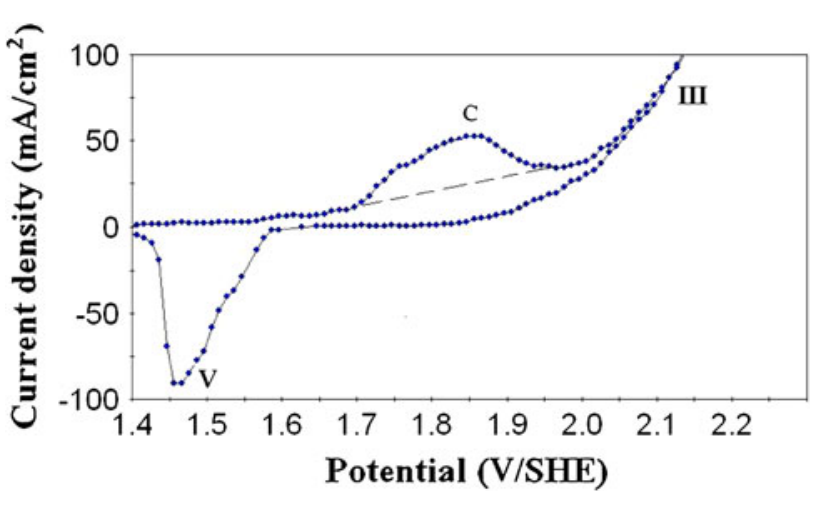

Fig. 10 Cyclic current-potential curve of the $\mathrm{Pb}-0.7 \% \mathrm{Ag}$ alloy anode at the second level at potential $1.62 \mathrm{~V}$ and decay of $50 \mathrm{~s}$ in a sulfuric acid solution $180 \mathrm{~g} / \mathrm{dm}^{3} \mathrm{H}_{2} \mathrm{SO}_{4}$ at a scan rate of $3 \mathrm{mV} / \mathrm{s}$

$\left(\mathrm{PbSO}_{4} \rightarrow \mathrm{PbO}_{2}\right)$ of Fig. 8 is more $14 \mathrm{~mA} / \mathrm{cm}^{2}$ than that of peak A of Fig. 9.

The sweep rates of Fig. 3, 5, 6 were increased from 3 to $300 \mathrm{mV} / \mathrm{s}$, the experiments were performed in a sulfuric acid concentration of $1.84 \mathrm{M} \mathrm{H}_{2} \mathrm{SO}_{4}$. It can be seen from Fig. 3 to 5 that the change of the sweep rates did not influence to a great extent the shape of CVs. All the cyclic voltammetric curves showed the redox reactions of lead. However, in Fig. 8 and 9, different results were obtained; when the sweep rate of $\mathrm{CV}$ reached $300 \mathrm{mV} / \mathrm{s}$, the highest current peak IV observed at lower scan rates cannot appear, and so the oxidation reaction: $\mathrm{O}_{2}+4 \mathrm{H}^{+}+4 e \rightarrow 2 \mathrm{H}_{2} \mathrm{O}$ had disappeared. No visible oxygen evolution was observed on the lead electrode during the cyclic experiments.

It is observed that the height of oxidation peak I increased with the increase of sweep rate, but that of the reduction peaks $\mathrm{V}$ decreased with the same rate in Fig. 5(b); this phenomenon was also found by Czerwinski et al. (Ref 10). This is because the higher sweep rate can lead to acceleration of oxidation reaction.

From the above results, it is found that $\mathrm{CV}$ technique is useful to understand the oxidation and reduction reactions of lead-silver and pure lead in acid solution. Comparing Fig. 3 with Fig. 4, following conclusions could be obtained: the addition of $\mathrm{MnSO}_{4}$ to the zinc electrolyte caused the disappearance of two oxidation peaks of the curves for lead-silver electrode. This should be because $\mathrm{MnSO}_{4}$ plays significant role in the anodic process, where it is intimately involved in the formation of oxide layers on $\mathrm{Pb}-\mathrm{Ag}$ anodes, and thus it helps to minimize the $\mathrm{Pb}$ content of zinc deposits (Ref 3).

Comparing Fig. 1 with Fig. 2, the current value of peak I $\left(\mathrm{Pb} \rightarrow \mathrm{PbSO}_{4}\right)$ of Fig. 2 is larger than that of peak I $(\mathrm{Pb} \rightarrow$ $\mathrm{PbSO}_{4}$ ) of Fig. 1; it means that pure lead is easier to corrosion than lead-silver anode in zinc electrolyte. Comparing Fig. 8 with Fig. 9, the current of peak $\mathrm{A}\left(\mathrm{PbSO}_{4} \rightarrow \mathrm{PbO}_{2}\right)$ of Fig. 9 is less than that of peak $\mathrm{A}\left(\mathrm{PbSO}_{4} \rightarrow \mathrm{PbO}_{2}\right)$ of Fig. 8; it means that with lead-silver anode it is easier to form $\mathrm{PbO}_{2}$ layer than with pure lead in zinc electrolyte. As reported by Ivanov et al. (Ref 1), $\mathrm{PbO}_{2}$ on the surface of anode has good electrical conductivity and electrocatalysis in zinc electrowinning, and hence, $\mathrm{Pb}-\mathrm{Ag}$ alloy anode has better electrochemical behavior than pure lead anode. It was found that silver played significant role in the reaction of anodes in zinc electrolyte by CV. The above results are in agreement with the hypothesis of Umetsu, et al. (Ref 20): alloying of silver in the alloys resulted in suppression of anodic oxidation of the materials, decrease in the anodic potential, formation of dense oxide layer closely adhering to the electrode, and appearance of $\mathrm{B}-\mathrm{PbO}_{2}$ in the anodic oxide layer. Also, Pavlov and Rogachev (Ref 21) believed that Ag enhances the formation of $\beta-\mathrm{PbO}_{2}$ at the oxide solution interface and in the zone close to the metal. In addition, adding Ag to lead anode can improve its mechanical properties and creep behavior since the mechanical properties of lead and its creep behavior in particular, are generally inadequate for this application. Owing to creeping of the lead under its own weight at operating temperature, the brittle lead oxide coating is broken up, and dissolved into the electrolyte to cause anode corrosion (Ref 1).

The molar volume of the $\beta-\mathrm{PbO}_{2}$ is $25 \mathrm{~cm}^{3} / \mathrm{mol}$, while that of the $\mathrm{PbSO}_{4}$ is $48 \mathrm{~cm}^{3} / \mathrm{mol}$. When the $\beta-\mathrm{PbO}_{2}$ was transited to the $\mathrm{PbSO}_{4}$ or the $\mathrm{PbSO}_{4}$ was transited to the $\mathrm{PbO}_{2}$, these transitions can result in a large increase or decrease of the molar volume of the surface layer. These changes might cause cracks in the surface layer of lead-silver alloy electrodes, thus exposing a bare metal surface instantly to $\beta-\mathrm{PbO}_{2}$, which is at the high anodic potential. Also the $\beta-\mathrm{PbO}_{2}$ is a good conductor; the oxygen evolves on the surface of $\beta-\mathrm{PbO}_{2}$.

Lead-silver had more dissolution peaks in sulfuric acid than those in zinc electrolyte, lead-silver dissolved more readily in sulfuric acid than in zinc electrolyte, and this is because the existing $\mathrm{ZnSO}_{4}$ can be beneficial to the formation denser layer of lead sulfate of lead-silver in zinc electrolyte than those in sulfuric acid, and hence, it is difficult for lead-silver to break the lead sulfate layer and to oxidize the metallic lead.

\subsection{Lead-Silver Alloy in Zinc Electrolyte During 16-h Decay}

$\mathrm{The} \mathrm{Pb}-\mathrm{Ag}$ anode sample was immersed for $16 \mathrm{~h}$ at the $\mathrm{OCP}$ in zinc electrolyte following 24-h polarization at $C D=50 \mathrm{~mA} / \mathrm{cm}^{2}$ at $38{ }^{\circ} \mathrm{C}$. The period of $16-\mathrm{h}$ potential decay can be divided into four levels: level 1: 1.72-1.66 V/SHE; level 2: 1.66-1.55 V/SHE; level 3: 1.55-0.9 V/SHE; and level 4: 0.9-0.3 V/SHE (Ref 22). The cyclic voltammeter was used to study the electrochemical behavior of the four levels of $\mathrm{Pb}-\mathrm{Ag}$ anodes in zinc electrolytic (Fig. 10).

Fig. 10 shows a CV diagram obtained after a decay period of $\sim 50 \mathrm{~s}$, after anodic polarization. This corresponds to the second decay period that has been detailed elsewhere (Ref 22). The oxidation peaks $\mathrm{C}$ and III and a reduction one $\mathrm{V}$ can be observed easily on this diagram. The first level is too short period (30 s) where the formed lead dioxide during anodization is still dominant. At the second level of decay, the most important is that the oxidation peak $\mathrm{C}$ corresponds to the oxidation reaction of $\mathrm{PbO} \cdot \mathrm{PbSO}_{4} \rightarrow \alpha-\mathrm{PbO}_{2}$. During the third level, less $\mathrm{PbO} \cdot \mathrm{PbSO}_{4}$ is expected because of its transfer to the stable $\mathrm{PbSO}_{4}$. Obviously, for the 4th level after $\sim 128 \mathrm{~min}$ for $0.7 \mathrm{Ag}$ lead, this reaction of oxidation of $\mathrm{PbO} \cdot \mathrm{PbSO}_{4}$ to $\mathrm{PbO}_{2}$ cannot be observed in a similar way to that of the second decay level since the residual amount of this compound is low. It is due to the non-thermodynamic stability of this compound at this range of potentials (0.9-0.3 V/SHE). This is already stated by Yamamoto et al. (Ref 23). The oxidation peak III corresponds to the reaction $\mathrm{O}_{2}+4 \mathrm{H}^{+}+4 e=2 \mathrm{H}_{2} \mathrm{O}$, and the reduction peak $\mathrm{V}$ should correspond to $\mathrm{PbO}_{2} \rightarrow \mathrm{PbSO}_{4}$ as described by Yamamoto et al. (Ref 4).

\subsection{XRD Results}

Figure 11 shows the x-ray diffraction (XRD) results for $\mathrm{Pb}-0.7 \% \mathrm{Ag}$ alloy anode at the first and fourth levels. 

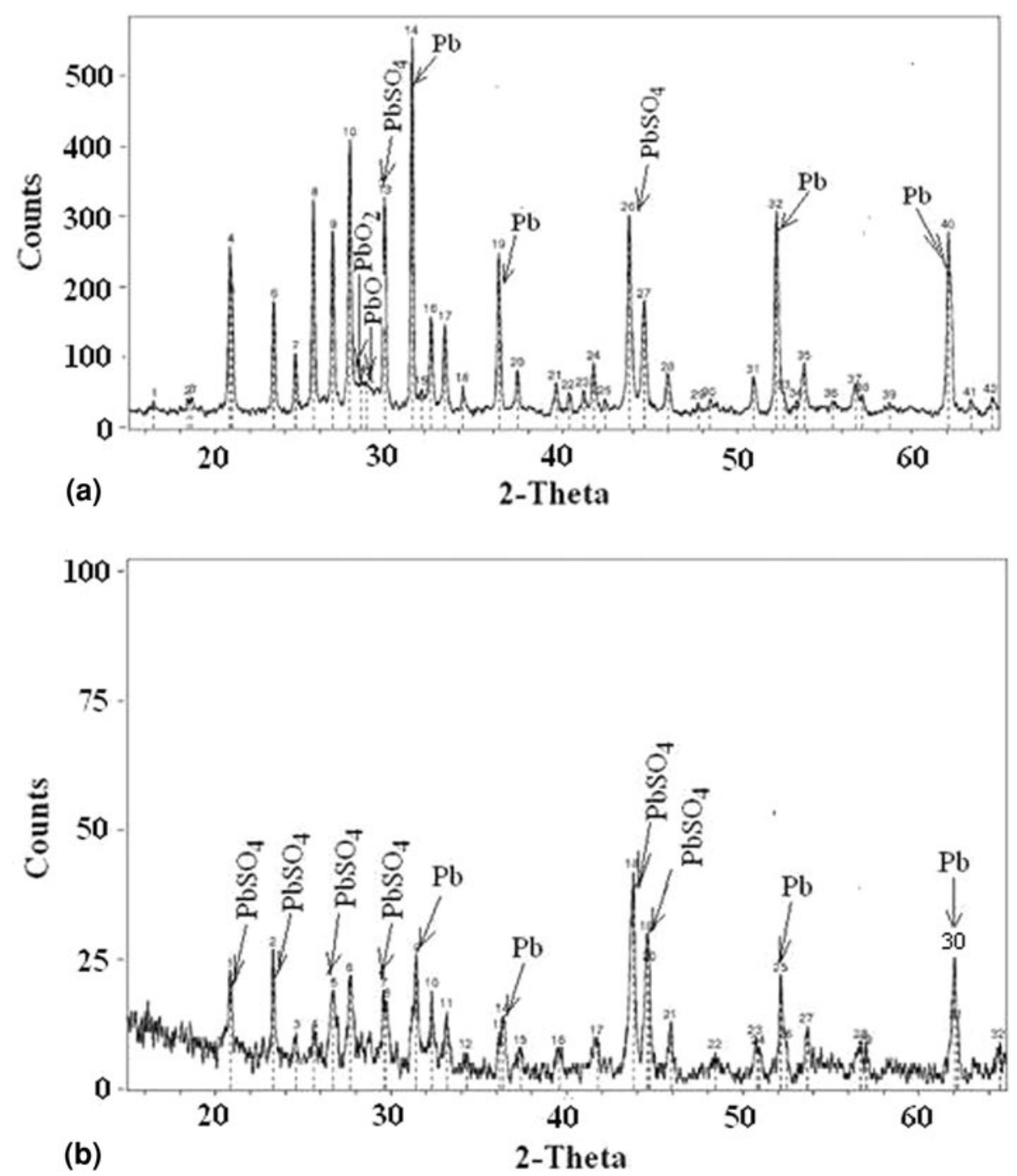

Fig. 11 X-ray powder diffraction, using $\mathrm{CuK}_{\alpha}$ radiation, of $\mathrm{Pb}, \mathrm{PbSO}_{4}, \mathrm{PbO}$, and $\mathrm{PbO}_{2}$ on the $0.7 \% \mathrm{Ag}$ anode at the decay potential of $1.72 \mathrm{~V} /$ SHE (first level) (a) and the potential decay of $0.85 \mathrm{~V}$ (fourth level) (b)

The diffractograms of $\mathrm{Pb}-0.7 \%$ Ag sample at $1.72 \mathrm{~V}$ show the presence of $\mathrm{Pb}, \mathrm{PbO}, \mathrm{PbSO}_{4}$, and lower intensity of the diffraction lines for $\mathrm{PbO}_{2}$ peaks (Fig. 11a). At the potential of $0.85 \mathrm{~V}$, almost all the $\mathrm{PbO}$ and $\mathrm{PbO}_{2}$ are replaced by $\mathrm{PbSO}_{4}$ for $\mathrm{Pb}-0.7 \% \mathrm{Ag}$ anode (Fig. 11b). It can be then admitted that the rate of decay from 1.72 to $0.85 \mathrm{~V}$ for $\mathrm{Pb}-0.7 \% \mathrm{Ag}$ alloy anode with a quick drop of voltage $\left(\mathrm{PbO}_{2} \rightarrow \mathrm{PbSO}_{4}\right.$ and $\mathrm{PbO} \rightarrow$ $\mathrm{PbSO}_{4}$ ) because of the quick formation of lead sulfate on the surface of the anode with silver content. Ag could be considered then as a dopant which affects the electrochemical characteristics of the $\mathrm{PbO}_{2} / \mathrm{PbSO}_{4}$, like $\mathrm{Co}^{2+}$ decreasing $\mathrm{PbO}_{2}$ quantity (Ref 24, 25).

\section{Conclusions}

In this article, the electrochemical redox behavior of lead and lead-silver alloy electrodes was investigated in sulfuric acid and zinc electrolyte using cyclovoltammetric method. After characterizing each redox peak, the following conclusions can be drawn:
1. CV technique has been used to observe redox peaks, and the associated species or products formed at these peaks could be characterized by chemical and physical methods, and XRD measurements confirm the results. This permits us to determine the influence of alloying elements such as $\mathrm{Ag}$ on the corrosion behavior of lead anodes.

2. Alloying pure lead with $0.7 \% \mathrm{Ag}$ for use as anode during zinc electrowinning decreased oxidation peak $(\mathrm{Pb} \rightarrow$ $\left.\mathrm{PbSO}_{4}\right)$ by $40 \%$ in sulfuric acid zinc electrolyte Also, $0.7 \%$ silver as alloying element increased the height of oxidation peak of $\left(\mathrm{PbSO}_{4} \rightarrow\right.$ b- $\left.\mathrm{PbO}_{2}\right)$ by $40 \%$.

3. The change of the sweep rate in $\mathrm{CV}$ experiments has an effect on the shape of CVs; at low sweep rate of $3 \mathrm{mV} / \mathrm{s}$, more redox peaks were observed than that at higher sweep rates. On the other hand, at the high sweep rate of $300 \mathrm{mV} / \mathrm{s}$, the $\mathrm{O}_{2}$ evolution peak disappeared.

4. Bubbling argon into the zinc electrolyte did not change the shape and number of redox peaks on the curve of $\mathrm{CV}$, and the addition of $\mathrm{MnSO}_{4}$ to the zinc electrolyte decreased the redox peaks on the curve for lead-silver anode in zinc electrolyte. 
5. During 16-h decay, the oxide peak $\left(\mathrm{PbO} \cdot \mathrm{PbSO}_{4} \rightarrow\right.$ a- $\mathrm{PbO}_{2}$ ) decreased with the level of decay from level 2 to 4 .

\section{Acknowledgments}

The authors are grateful to the Hydro-Quebec, CEZ, and the Natural Sciences and Engineering Research Council of Canada (NSERC) for their financial support.

\section{Open Access}

This article is distributed under the terms of the Creative Commons Attribution License which permits any use, distribution, and reproduction in any medium, provided the original author(s) and the source are credited.

\section{References}

1. I. Ivanov, Y. Stefanov, Z. Noncheva, M. Petrova, Ts. Dobrev, L. Mirkova, R. Vermeersch, and J.-P. Demaerel, Insoluble Anodes Used in Hydrometallurgy: Part I. Corrosion Resistance of Lead and Lead Alloy Anodes, Hydrometallurgy, 2000, 57, p 109-124

2. T. Nguyen and A. Atrens, Composition and Morphology of the Film Formed on a Lead Alloy Under Conditions Typical of the ElectroWinning of Copper, Hydrometallurgy, 2009, 96, p 14-26

3. D.J. Mackinnon, The Effects of Foaming Agents, and Their Interaction with Antimony, Manganese and Magnesium, on Zinc Electrowinning from Synthetic Acid Sulphate Electrolyte, Hydrometallurgy, 1994, 35, p 11-26

4. Y. Yamamoto, K. Fumino, T. Ueda, and M. Nambu, A Potentiodynamic Study of the Lead Electrode in Sulphuric Acid Solution, Electochem. Acta, 1992, 37, p 199-203

5. D. Pavolv, Processes in Solid State at Anodic Oxidation of a Lead Electrode in $\mathrm{H}_{2} \mathrm{SO}_{4}$ Solution and Their Dependence on the Oxide Structure and Properties, Electrochim. Acta, 1978, 23, p 845-854

6. D. Pavolv and T. Rogachev, Dependence of the Phase Composition of the Anodic Layer on Oxygen Evolution and Anodic Corrosion of Lead Electrode in Lead Dioxide Potential Region, Electrochim. Acta, 1978, 23, p 1237-1242

7. D. Pavlov, E. Bashtavelova, D. Simonsson, and P. Ekdunge, Processes at the Micro-Level in the Oxidation of $\mathrm{PbSO}_{4}$ to $\mathrm{PbO}_{2}$ During Charging of Lead/Acid Battery Positive Plates, J. Power Sources, 1990, 30, p 77-97

8. T.K.T. Nguyen, "A Study of the Mechanism by Which Cobalt Ions Minimize Corrosion of Lead Alloy Anodes During Electrowinning of Base Metals," Ph.D. Thesis, University of Queensland, Australia, 2007, p 7-8

9. M.N.C. Ijomah, Electrochemical Behavior of Some Lead Alloys, J. Electrochem. Soc., 1987, 134, p 2960-2966
10. A. Czerwinski, M. Zelazowska, M. Grden, K. Kuc, J.D. Milewski, A. Nowacki, G. Wojcik, and M. Kopczyk, Electrochemical Behavior of Lead in Sulfuric Acid Solutions, J. Power Sources, 2000, 85, p 49-55

11. C. Rerolle and $\mathrm{R}$. Wiart, Kinetics of $\mathrm{Pb}$ and $\mathrm{Pb}-\mathrm{Ag}$ Anodes for Zinc Electrowinning- $\mathrm{I}$. Formation of $\mathrm{PbSO}_{4}$ Layers at Low Polarization, Electrochim. Acta, 1995, 40, p 939-948

12. S. Krzewska, L. Pajdowski, H. Podsiadly, and J. Podsiadly, Electrochemical Determination of Thiourea and Glue in the Industrial Copper Electrolyte, Metall. Trans. B, 1981, 15B, p 451-459

13. ASTM Publication, Standard Test Method for Conducting Cyclic Potentiodynamic Polarization Measurements for Localized Corrosion Susceptibility of Iron-, Nickel, or Cobalt-Base Alloys, ASTM G61-86, PA, 2001, 03.02, p 231-235

14. S.C. Barnes and R.T. Mathieson, The Potential pH Diagram of Lead in the Presence of Sulphate Ions and Some of Its Implications in LeadAcid Battery Studies, Batteries, D.H. Collins, Ed., Pergamon Press, New York, 1963, p 41-54

15. P. Jones and H.R. Thirsk, An Electrochemical and Structural Investigation of the Processes Occurring at Silver Anodes in Sulphuric Acid, Trans. Faraday Soc., 1954, 50, p 732-738

16. R.L. Deutscher, S. Fletcher, and J.A. Hamilton, Invention of Cyclic Resistometry, Electrochim. Acta, 1986, 31, p 585-589

17. V. Danel and V. Plichon, The Electrochemical Oxidation of Lead in Various $\mathrm{H}_{2} \mathrm{O}-\mathrm{H}_{2} \mathrm{SO}_{4}$ Mixtures-I. Linear Sweep Voltammetry, Electrochem. Acta, 1983, 28, p 781-784

18. B.K. Mahato and W.H. Tiedemann, Linear Potential Sweep of LeadAcid Battery Electrodes Containing Trace Te, Sb, As, Co., and Ni, J. Electrochem. Soc., 1983, 130, p 2139-2144

19. M. Pourbaix, Atlas of Electrochemical Equilibria in Aqueous Solutions, National Association of Corrosion Engineers, Houston, TX, 1974

20. Y. Umetsu, H. Nozoka, and K. Tozawa, Anodic Behaviour of Pb-Ag Alloys in Sulfuric Acid Solution, Proceedings of the International Symposium on Extract. Metall. Zinc, MMJ, Tokyo, Japan, 1985, p 265-279

21. D. Pavlov and T. Rogachev, Mechanism of the Action of Ag and As on the Anodic Corrosion of Lead and Oxygen Evolution at the $\mathrm{Pb}$ / $\mathrm{PbO}(2-x) / \mathrm{H}_{2} \mathrm{O} / \mathrm{O}_{2} / \mathrm{H}_{2} \mathrm{SO}_{4}$ Electrode System, Electrochim. Acta, 1986, 31, p 241-249

22. W. Zhang, A.-M. Lafront, E. Ghali, and G. Houlachi, Influence of Silver Content on Corrosion Resistance of Lead Anodes During Potential Decay by Electrochemical Noise Measurements, METSOC, Development \& Performance of Sulphur Capture Plants (Sudbury, ON, Canada), 48th Annual Conference of Metallurgists of CIM, 2009, p 101-115

23. Y. Yamamoto, M. Matsuoka, M. Kimoto, M. Uemura, and C. Iwakura, Potentiodynamic Reactivation of a Passivated Lead Negative Electrode in Sulphuric Acid, Electrochim. Acta, 1996, 3, p 439-444

24. N. Chahmana, M. Matrakova, L. Zerroual, and D. Pavlov, Influences of Some Metal Ions on the Structure and Properties of Doped $\beta-\mathrm{PbO}_{2}$, J. Power Sources, 2009, 191, p 51-57

25. N. Chahmana, L. Zerroual, and M. Matrakova, Influence of $\mathrm{Mg}^{2+}$, $\mathrm{Al}^{3+}, \mathrm{Co}^{2+}, \mathrm{Sn}^{2+}$ and $\mathrm{Sb}^{3+}$ on the Electrical Performance of Doped $\beta$-Lead Dioxide, J. Power Sources, 2009, 191, p 144-148 